\title{
Plickers: A Tool for Language Assessment in the Digital Age
}

\author{
R. Jinu, S. Shamna Beegum
}

\begin{abstract}
Applied science and technology has brought a revolution to the world of English language teaching. From teacher oriented classrooms there is a shift towards paido centric learning. This paper discusses how important is formative assessment in a language course and how web-based assessment has transformed formative assessment positively in an ELT classroom.
\end{abstract}

Keywords--- Technology, Applied Sciences, Web-based Assessment and Formative Assessment.

\section{INTRODUCTION}

Man always crave for knowledge and this has resulted in his makeover from time to time. The revolution internet and technology has brought to our lives stand as one of the exemplary examples of applied sciences. Not even a single second can be imagined without science and technology. The invention of the printing press which marked the uprising of human knowledge has now reached its peak with PCs, Smartphones, I phones, iPads etc. marking anew era in the history of mankind.

The impact of technology is seen everywhere, especially in the field of education. The learners at the tertiary level are digital natives and hence the digital immigrant teacher has a comparatively diminished role in the paido centric or learning centric learning environment. But the role, the teacher plays as a process manager, has greater responsibilities in shifting the paradigms of classroom teaching. Though massive open online courses, global open are new to the rural learners of India, it cannot be merely side-lined in Indian classrooms in the forthcoming years. Language learning is not an easy task for many second language learners. Stephen Krashen's input hypothesis advocates that acquiring a language demands 'comprehensible input'. Frequent monitoring of learner's comprehension is important for providing the feedback in a language learning course. Assessment and providing feedback are therefore part of testing the learner's comprehension.

According to Chappuis, Stiggins \& Arter (2012)feedback is intended to be given to the student or teacher with a purpose of providing the results about his or her performance and these outcomes have to lead to upgraded performance. Formative assessment provides in progress feedback to learners. Shepard (2005) considers formative assessment as a crucial element of instruction in the contemporary models of teaching and learning. Error detection and correction in a second language learner has to

Revised Manuscript received July 10, 2019.

R. Jinu, Department of English, Noorul Islam Centre for Higher Education, Kumaracoil, Kanyakumari District, T.N, India.

S. Shamna Beegum, Research Scholar, Department of English, Noorul Islam Centre for Higher Education, Kumaracoil, Kanyakumari District, T.N, India. (e-mail: shamnaansar@email.com) online courses, online teaching and learning, E-learning etc.

be done before it gets fossilised. As per Hughes (1998), the feedback, to be maximum effective, must be given as soon as the error occurs. When it is done so, learners understand the mistakes in their responses. This in turn reduces the likelihood of recurring errors and thereby enhances learning. When fluency alone is focused immediate feedback can be secondary. Errors have to be rectified during the formative stage and hence formative assessment has to be conducted periodically to ensure the progress of learners and to provide feedback. William (2006) opines that the most important reason to use formative assessment is that it permits for feedback during instruction. But Formative Assessment is a time-consuming process in a language classroom. To Cizek (2010), formative assessment, includes gathering evidence of learners' strengths and weaknesses which has to aid designing further instructions, to help develop selfevaluation, learner autonomy, and skill building. Hence educators should endeavour to make their feedback as clear and specific as far as possible because specific feedback is more effective than general feedback suggests, Shute (2008). The learner should get to know what is appropriate and inappropriate. This is mostly done with the help of the assignments and tasks given to the learner in the classrooms by way of internal assessment. Though formative assessment assess the learner at regular intervals it has low weightage when compared to the benchmarked summative assessment. Moreover faculty are mostly blamed for being biased during the formative assessments. For these reasons it turns to be frustrating and time consuming for educators. Computer-assisted language testing (CALT) now known as web-based testing (WBT) is gaining popularity and has been used pan globe since 1985 after realising its advantages in delivering test items. Such assessments ensure accuracy and speed, replacing paper and pencil with electronic gadgets.

\section{PLICKERS: A WEB 2.O ASSESSMENT TOOL \& RESULTS}

Plickers is a web tool that can be used for formative assessment even in a low technology classroom and hence found immensely beneficial to classrooms in rural south India where restrictions marginalise the 'Bring Your Own Device' concept. For its application, it requires only one computer, the Plickers mobile app installed to a smartphone and Plickers assessment cards. It has been proved to be an effective, timesaving, easy to use Edu tech tool that can be used in Indian classrooms. According to Brookhart (2001), the form of assessment is not very important. What matters the most is that how educators/ learners interpret, self-assess and integrate the test results, into their teaching / learning process. 
The test results are to be carried out positively and have to be used for reflective teaching and remedial teaching by the educators. Learners have to utilize it to understand where their learning stagnates and take it as a motivational factor and strategize to reach desired outcomes. According to Brookhart (2008) although teachers give and get feedback in their everyday teaching, very few understands its importance in the teaching learning process. The significance of formative assessments are often underestimated.

\section{WHY PLICKERS?}

Plickers is an easy rapid-response classroom-app, with a user-friendly interface, suitable to be used for any age group. It is a simple concept that can be used in a language classroom where the learners need not use any gadgets. Plickers help teacher in reflective teaching, remedial teaching and on-the-spot formative assessment. Good bye to boring evaluation makes Plickers an attractive tool. Data can be collected in a click. It is very useful for 'No written examination courses', practical sessions etc. It can be blended with other oral tests or quizzes.

Plickers has cost effective as well as free plans for educators. The free plan is more than enough to serve an educator. A teacher has to create an account in the web any email account is enough to create a free account.

https/muw.plickers com/login

\section{$\checkmark$ plickers}

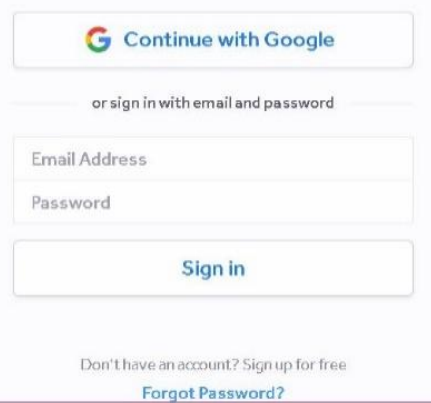

Once the free account is created, create the class where the assessment is to be conducted. The learners' names are then plugged in and card numbers are assigned to them. Questions are created and added to que, and then the questions are played. Once the learners show their response using the Plickers response cards allotted to them, the teacher starts scanning the learners' responses using the app installed in the mobile phone.

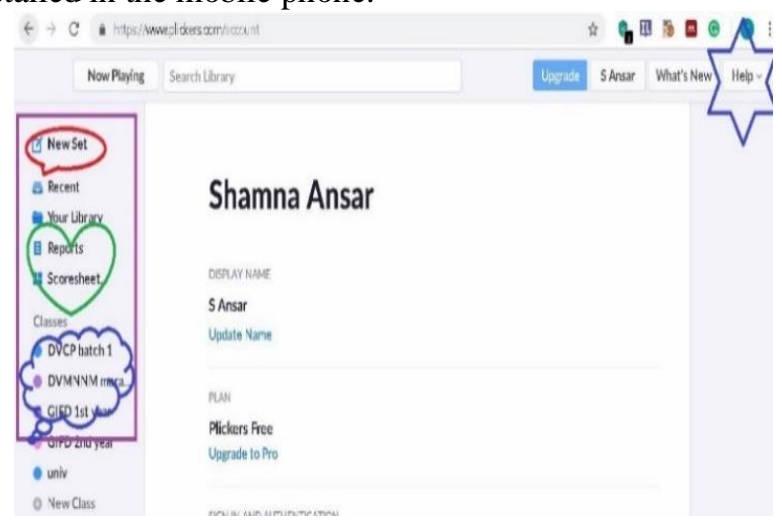
interface https://www.plickers.com. A gmail account or

Plickers apps are available for iOS and Android mobiles. Cards for the learners' responses, links to apps and other useful links can be found under the help menu.

\begin{tabular}{|l|l|l|}
\hline Upgrade & S Ansar & What's New \\
\hline & Library and Recent Help \\
\hline Plickers Help Home \\
Getting Started Guide \\
Get Plickers Cards \\
Get iOS App \\
Get Android App \\
Upgrade to Pro \\
Contact Plickers
\end{tabular}

Plickers cards can either be printed choosing them from the set, or can be purchased through Amazon as per the requirement.
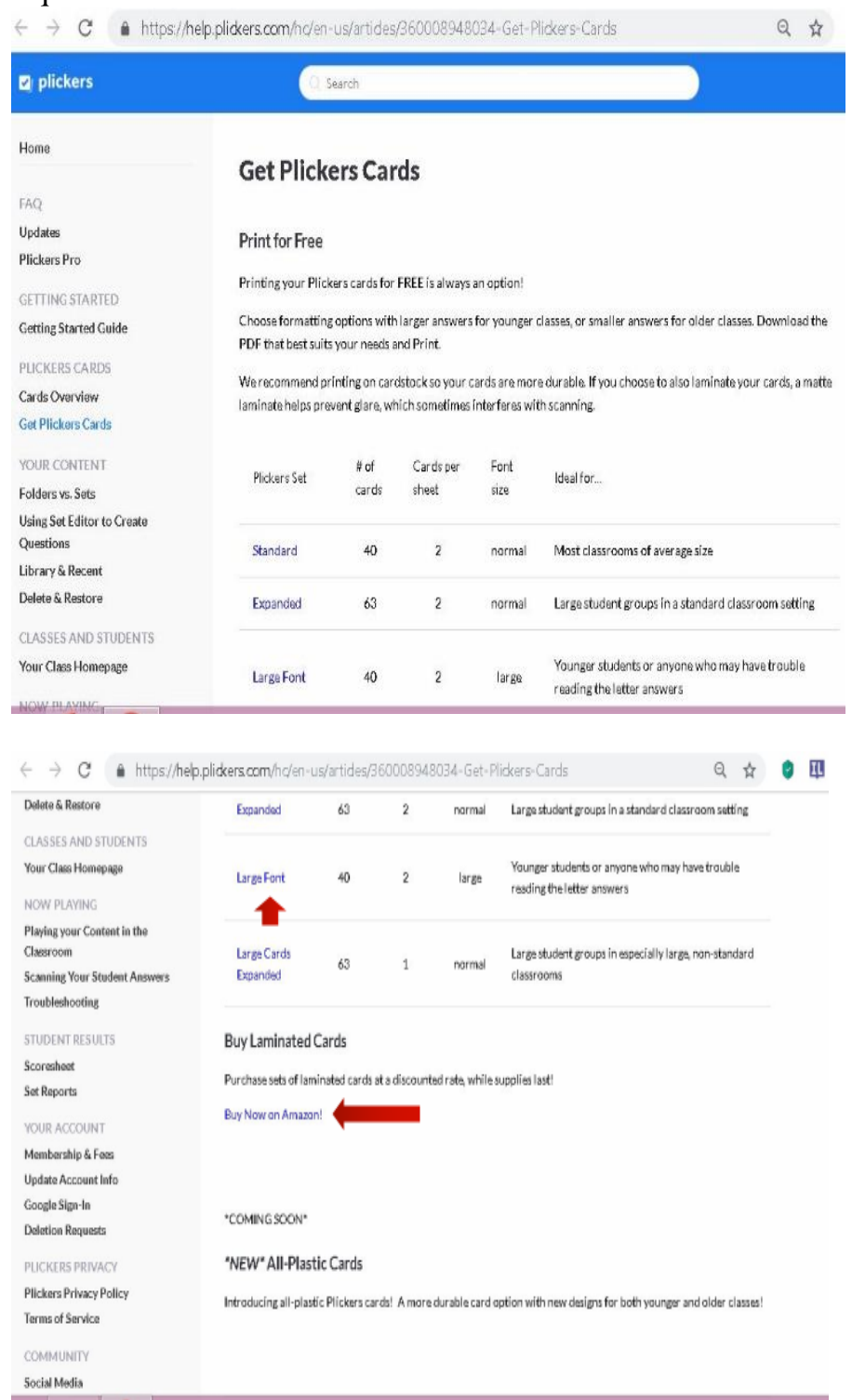

Published By:

Blue Eyes Intelligence Engineering

\& Sciences Publication

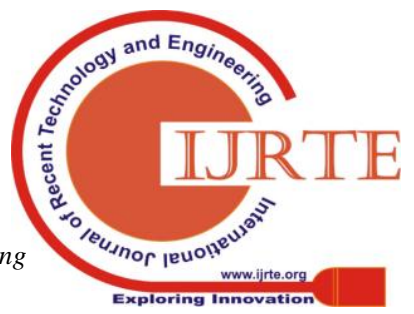




\section{Sample Plickers card}

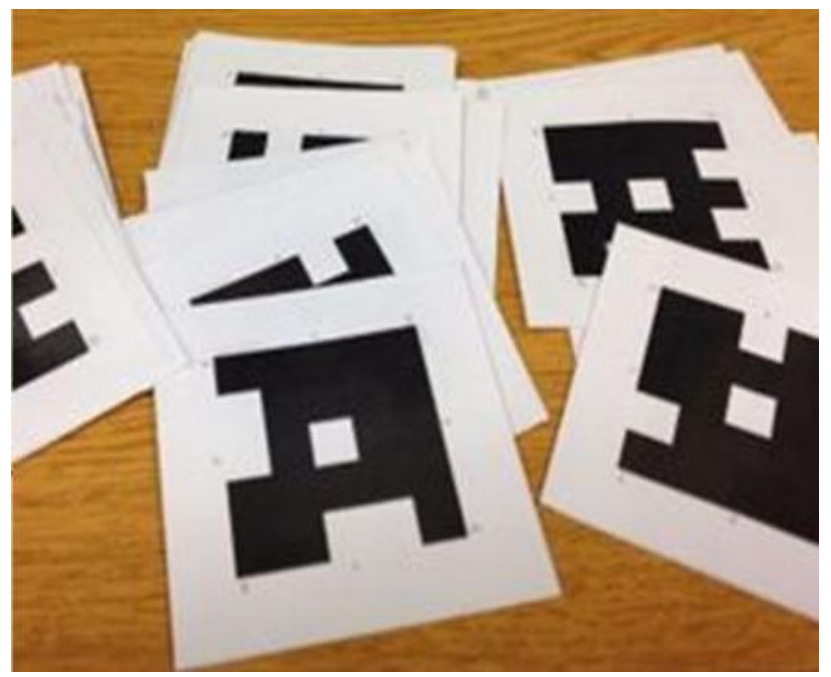

The teachers can create as many number of question sets, each carrying five questions using a free account. Questions can be graded. It can be created as survey, if no marks are intended to be allotted. It can be set as multiple choice or True/False type.

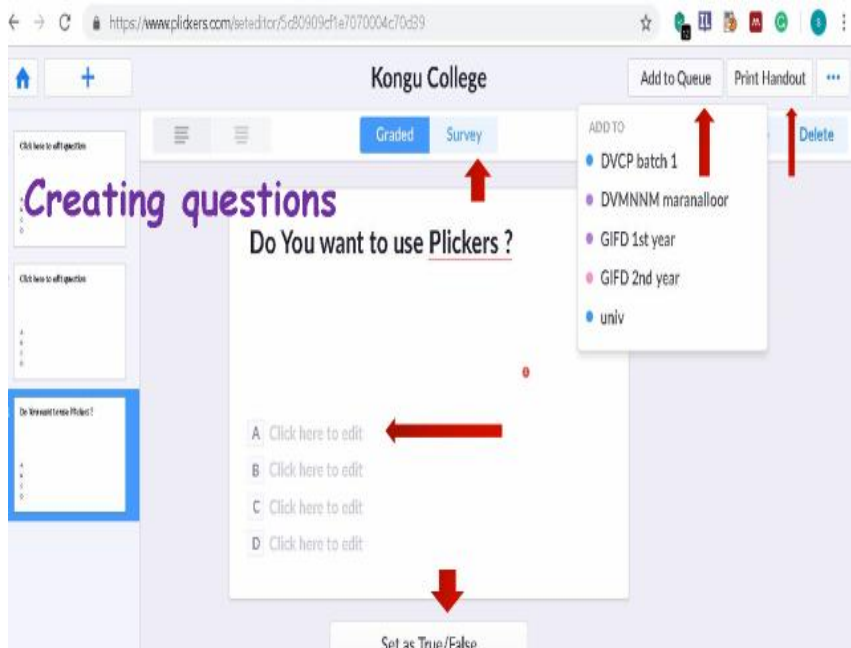

Option is available to create a new class and the questions created can be found under 'Your Library' in the dash board.

\begin{tabular}{|c|c|c|}
\hline Now Paying & \multicolumn{2}{|l|}{ Sench barary } \\
\hline \multirow{2}{*}{$\begin{array}{l}\square \text { NewSet } \\
\Delta \text { Recent }\end{array}$} & - Your Library & 『New Set \\
\hline & \multirow{2}{*}{$\begin{array}{l}\text { NaMe } \\
\text { S Manivinikerlanl }\end{array}$} & MOOFFED \\
\hline 目 Reports & & 1700 8018 \\
\hline II Scoresheet.. & 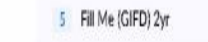 & $2000 \times 2018$ \\
\hline $\begin{array}{l}\text { Classes } \\
\text { O DVCP batch1 }\end{array}$ & 5 Find $M e$ & $170 \times 2018$ \\
\hline \multirow{2}{*}{$\begin{array}{l}\text { O DVMNNMmara. } \\
\text { ofFD Istyear }\end{array}$} & 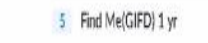 & 200esis \\
\hline & 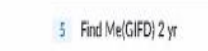 & $2000 \times 2018$ \\
\hline \multirow{2}{*}{$\begin{array}{l}\text { GlFD and year } \\
\text { Ouniv } \\
\text { O New Class }\end{array}$} & 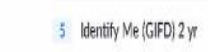 & Yodecolis \\
\hline & \& My Engish & 180ecedis \\
\hline
\end{tabular}

Classes can be archived, made active or deleted as per the requirement.

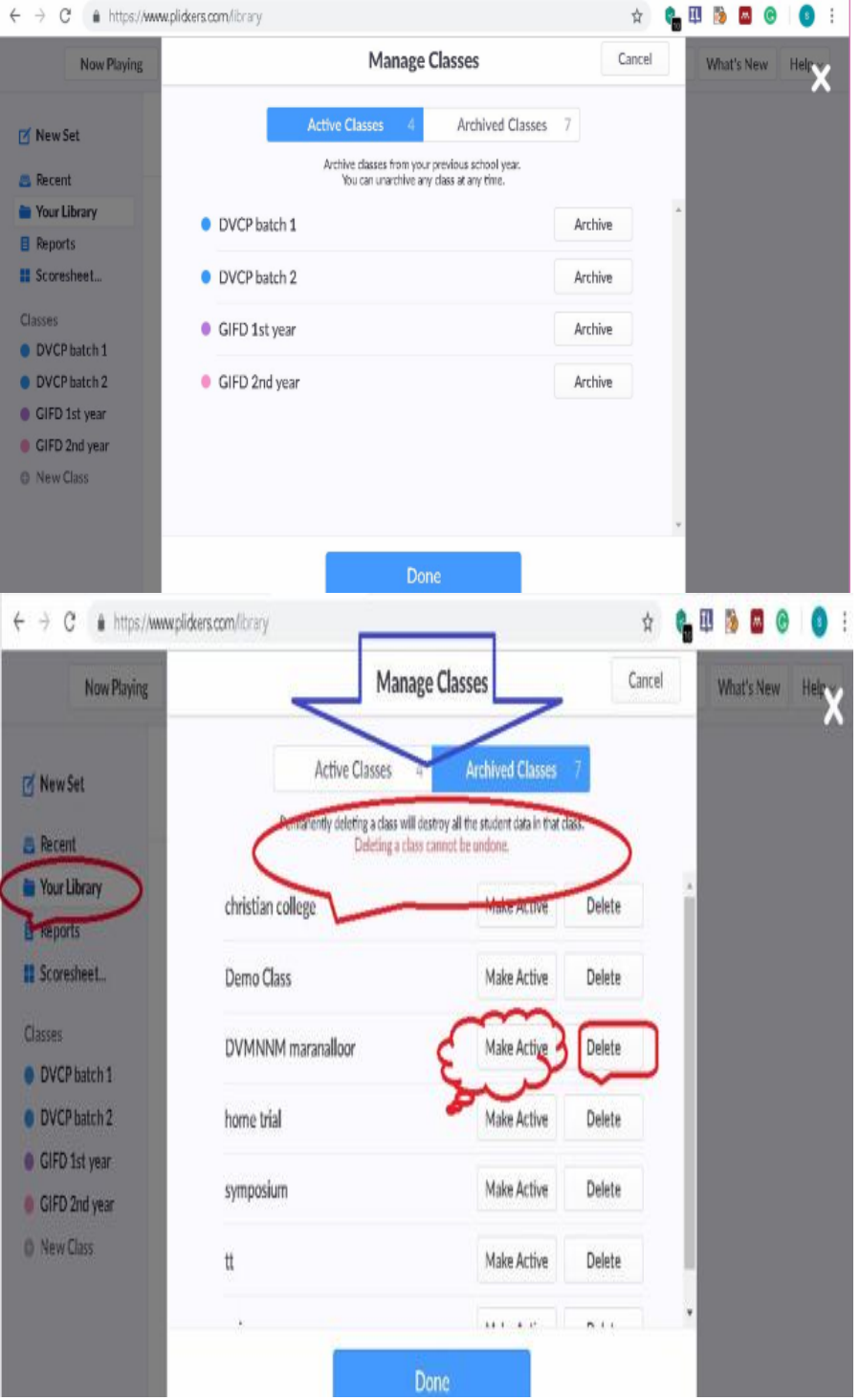

Mobile view of Plickers App

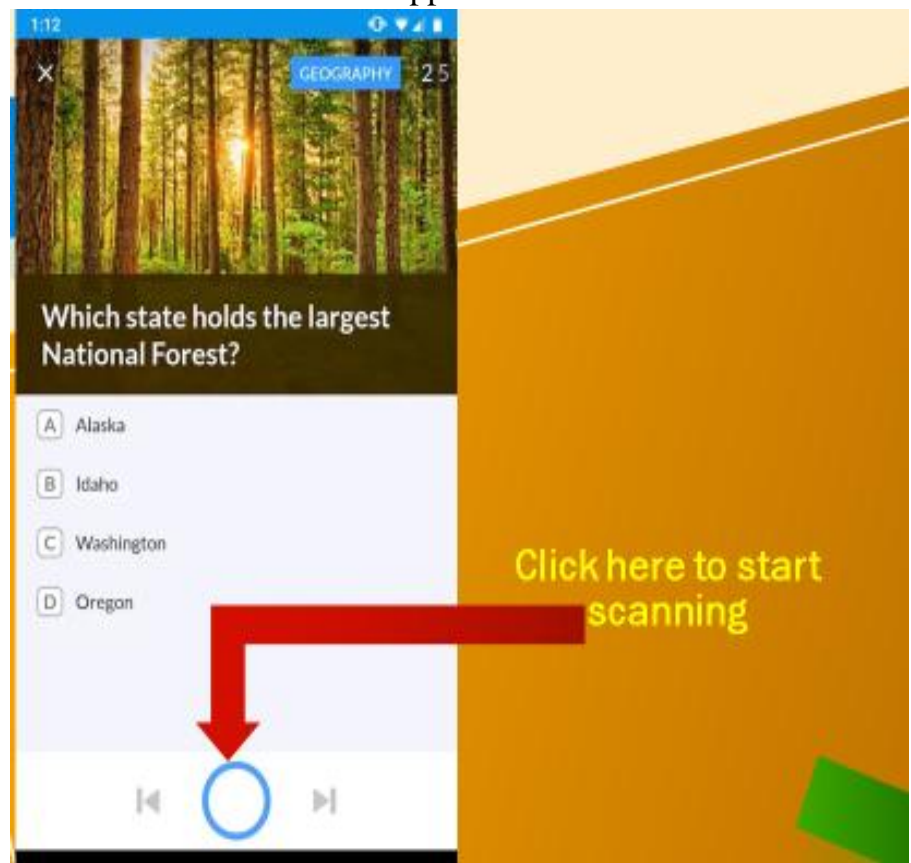

The reports can be generated on the spot

Published By:

Blue Eyes Intelligence Engineering

\& Sciences Publication

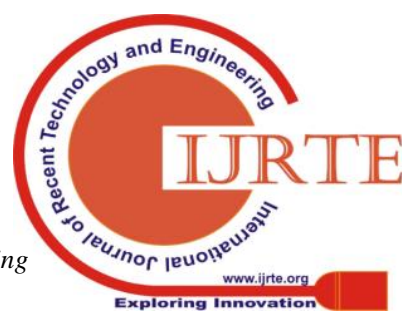


PLICKERS: A TOOL FOR LANGUAGE ASSESSMENT IN THE DIGITAL AGE

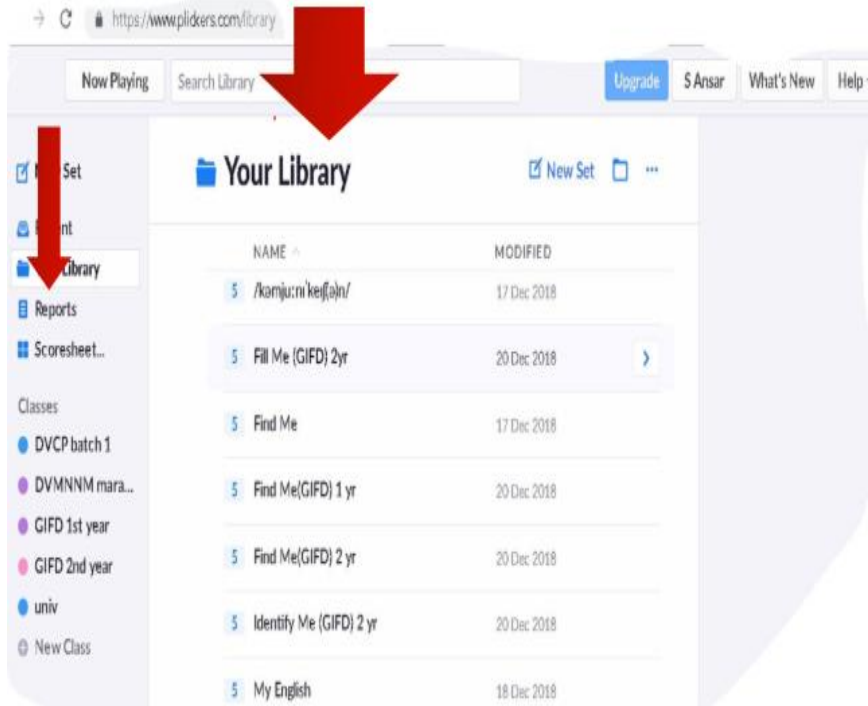

The teacher can reflect on his/her teaching methodology.

These reports indicate the performance of the whole class. According to Cizek (2010) formative assessment should provide information to the teacher or learners and this has to be used to modify teaching and improve learning.

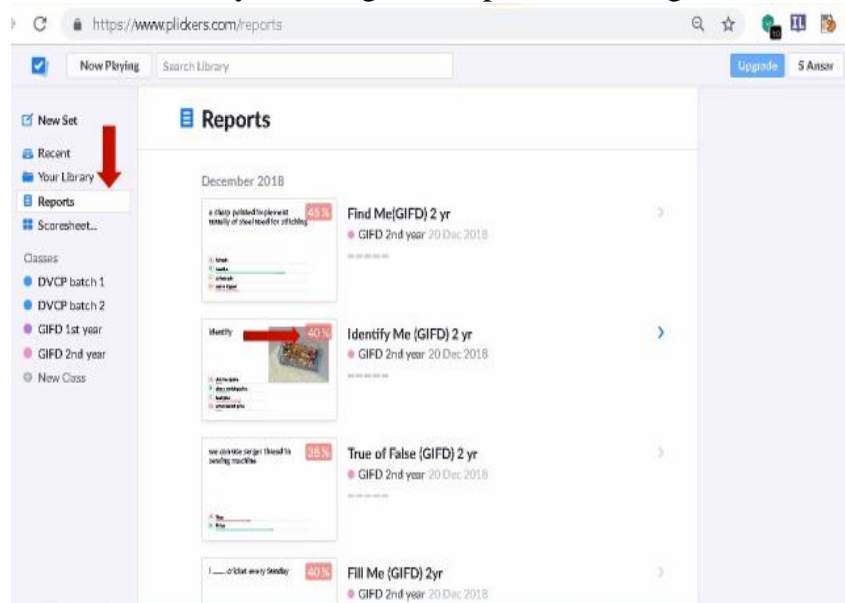

The score sheet helps the teacher to get individual learner report which can be used to plan remedial teaching. In the score sheet the teacher can either get the percentage score display or the correct/total split of the candidate.

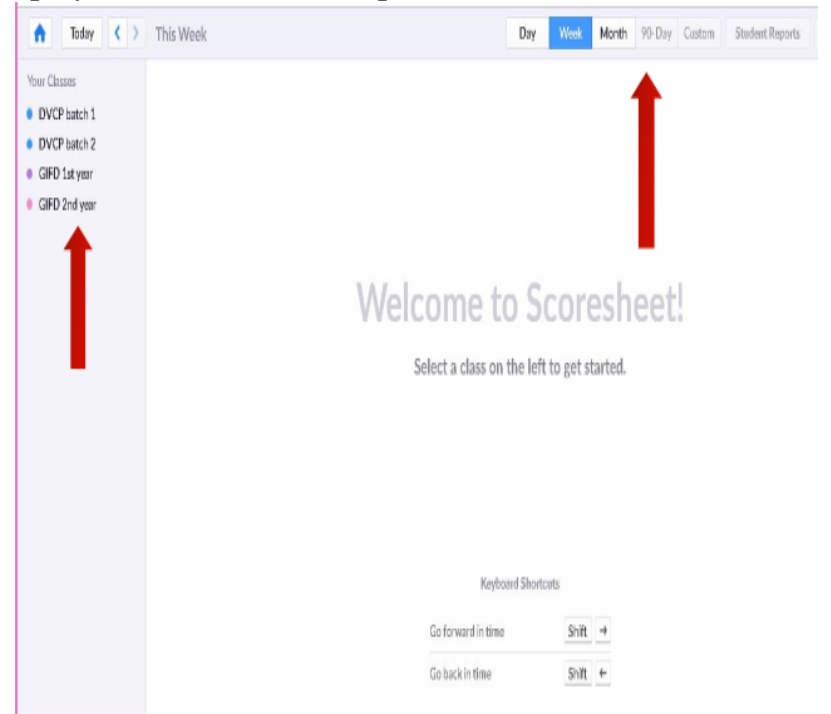

The assessment report scores given below show that the teacher has to focus on teaching pronunciation.
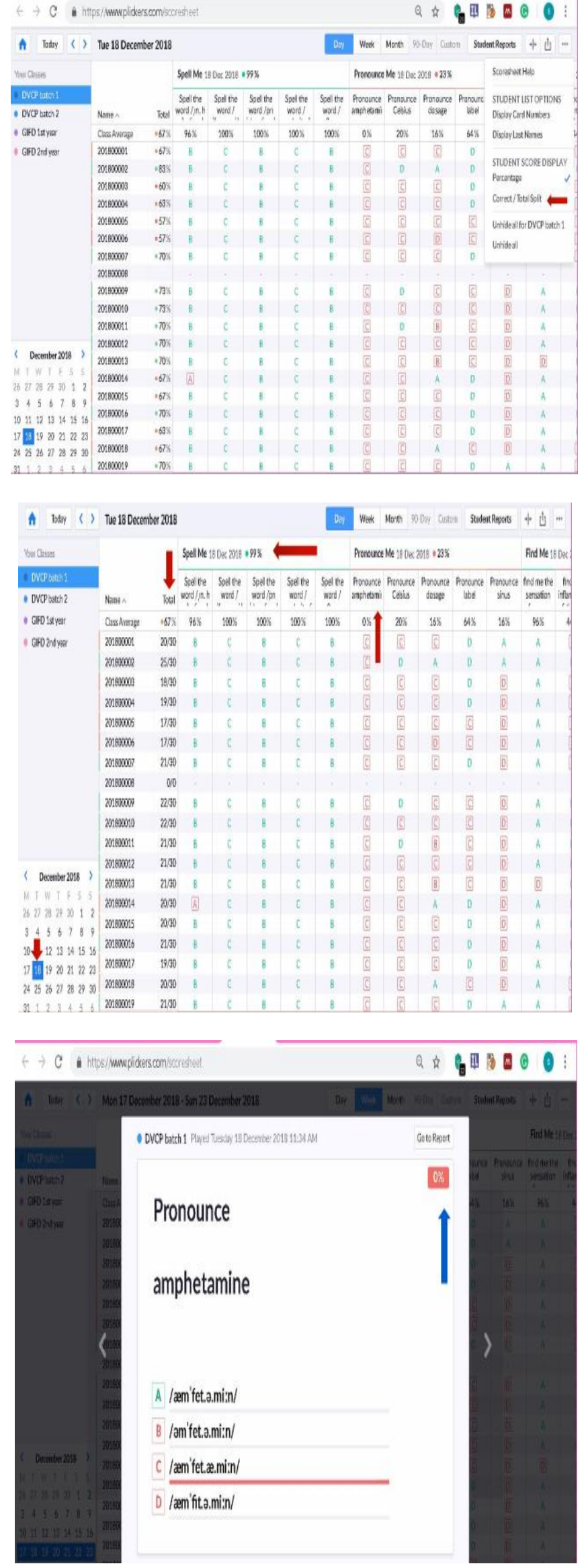

Published By: 


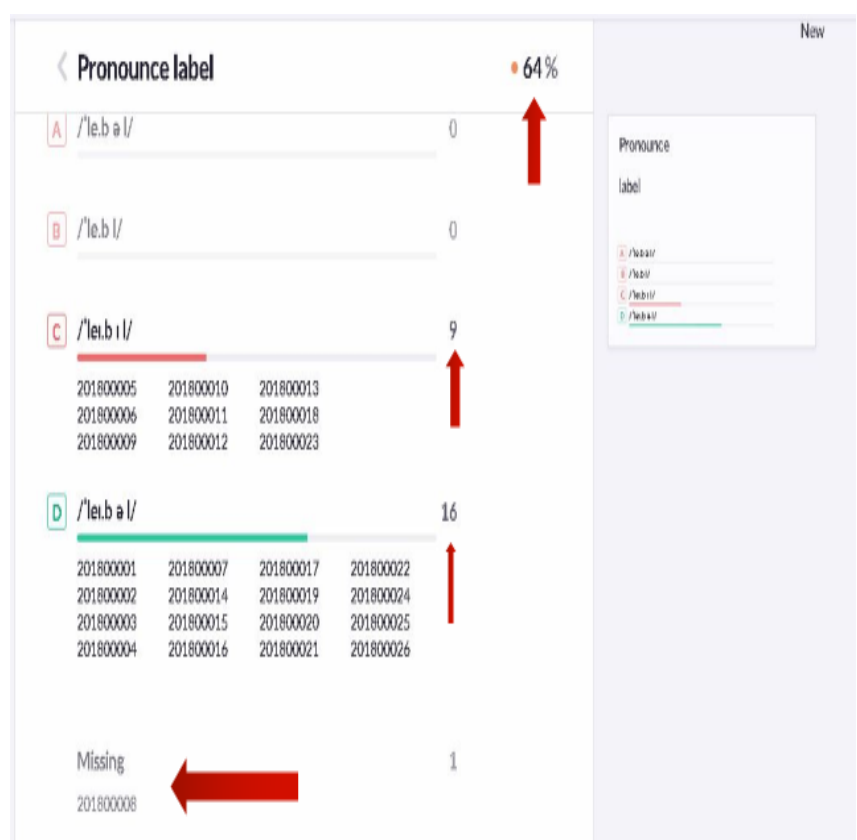

The report given below shows that the teacher no more need to focus teaching spellings

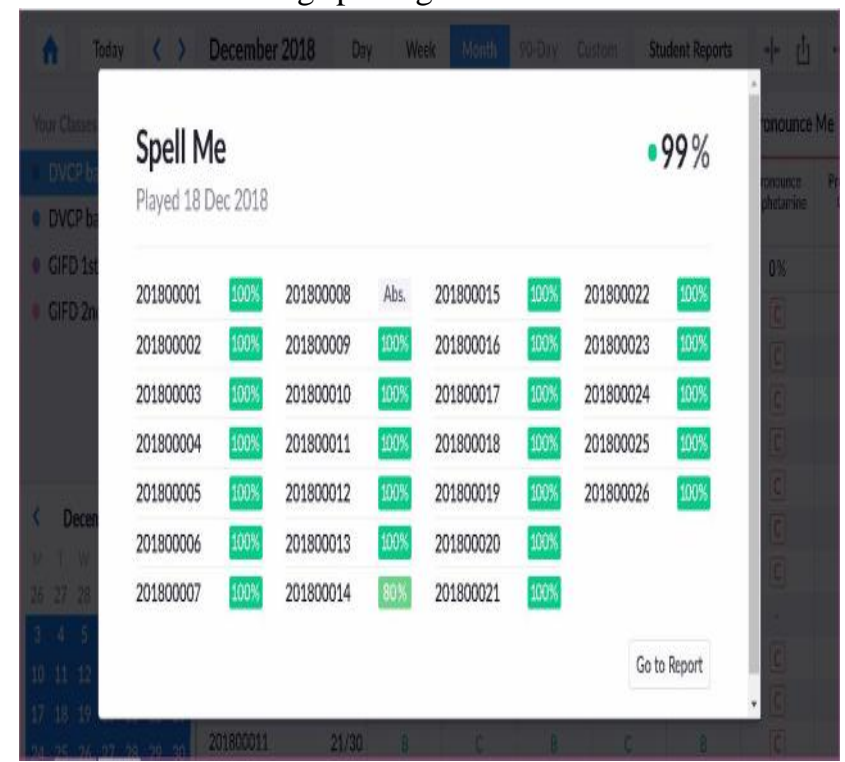

The score sheets can be viewed and printed in either collapsed mode or detailed mode

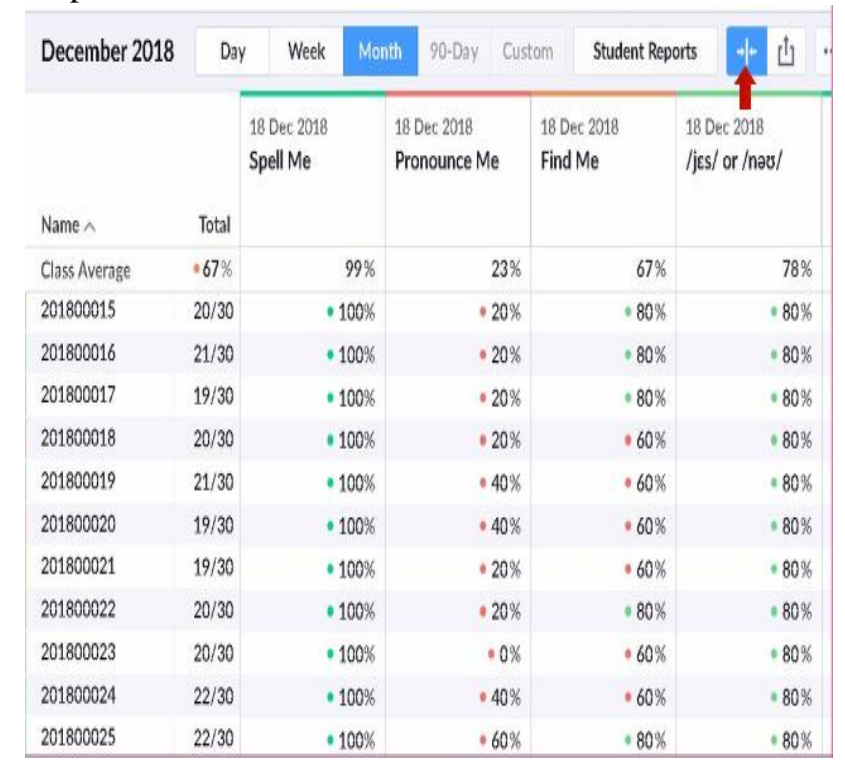

\begin{tabular}{|c|c|c|c|c|}
\hline $\begin{array}{l}\text { Spell the word } \\
/, \mathrm{n}, \mathrm{h} \text { a }^{2} \text { lel.fo } \\
\mathrm{n} /\end{array}$ & $\begin{array}{l}\text { Spell the word } \\
\text { /fa:.ma.si/ }\end{array}$ & $\begin{array}{l}\text { Spell the word } \\
\text { /pri'skrip. } f \text { an/ }\end{array}$ & $\begin{array}{l}\text { Spell the word } \\
\text { /.prel.pit'tel.fo } \\
\mathrm{nz} /\end{array}$ & 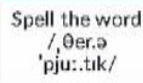 \\
\hline $96 \%$ & $100 \%$ & $100 \%$ & $100 \%$ & $100 \%$ \\
\hline B & C & B & c & B \\
\hline B & C & B & C & B \\
\hline B & C & B & C & B \\
\hline B & C & B & C & B \\
\hline B & C & B & C & B \\
\hline B & C & B & C & B \\
\hline B & C & B & C & B \\
\hline B & c & B & c & B \\
\hline B & c & B & c & B \\
\hline B & C & B & C & B \\
\hline B & C & B & C & B \\
\hline
\end{tabular}

Alternative tool

Qcmcam \{https://qcmcam.jeduque.net \}is the only alternative tool available for Plickers as of now. This French website supports latex formulas and can help math formative assessments but a warning stating that it can crash any time was found on the webpage and hence it was not tried.

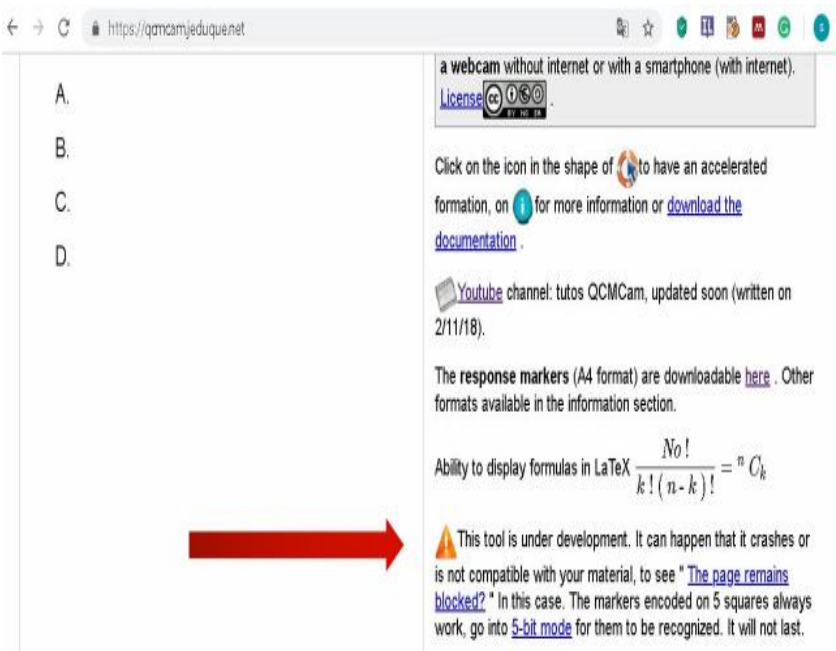

\section{CONCLUSION}

When asked about the assessment conducted using Plickers, the learners were very happy. They found it simple and easy and felt that they were free from anxiety during the assessment. Using Plickers for assessment, helps a teacher to gain insight about the wash back. Teacher can easily plan remedial teaching and help those learners strategize activities according to their requirements. The results gives the teacher and learners actionable feedback as suggested by Hattie and Timperley (2007). Formative assessments have to be taken as constructive feedbacks. Learners should take it as an opportunity to set their learning goals, understand and appreciate their progress, plan further activities to catalyse the progress and know how to close the gap between their performance and mastery.

Published By:

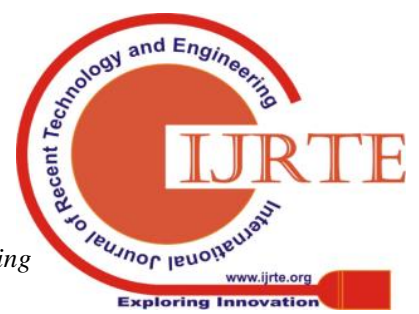




\section{REFERENCES}

1. www.plickers.com

2. https://qcmcam.jeduque.net

3. Bransford (Eds.), Preparing teachers for a changing world (pp.275-326).SanFrancisco: John Wiley.

4. Brookhart, S. 2001. "Successful Students Formative and Summative Uses of Assessment Information." Assessment in Education: Principles, Policy and Practice 8 (2): 153-169. Doi: 10.1080/09695940123775.

5. Brookhart, S. M. (2008). How to give effective feedback to your students. Alexandria, VA: Association for Supervision and Curriculum Development.

6. Brophy, J. (1986). Teacher influences on student achievement. American Psychologist, 41, 1069-1077.

7. Chan., etal (2014).The critical role of feedback in formative instructional practices: Intervention in School and Clinic

8. Chappuis, J., Stiggins, R., Chappuis, S., \& Arter, J. (2012). Classroom assessment for student learning: Doing it right - using it well. Boston, MA: Pearson.

9. Cizek, G. 2010. 'An introduction to formative assessment: history, characteristics, and challenges' in $\mathrm{H}$. L. Andrade and G. J. Cizek (eds.)

10. Hattie, J. (2012). Visible learning for teachers: Maximizing impact on learning. New York, NY: Routledge

11. Hattie, J., \& Timperley, H. (2007). The power of feedback. Review of Educational Research, 77, 81-112

12. Hughes, C. (1998). Effective instruction for adults with learning disabilities. In B. K. Lenz, N. A. Sturomski, \& M. A. Corley (Eds.), Serving adults with learning disabilities: Implications for effective practice (pp. 2743). Washington, DC: National Adult Literacy and Learning Disabilities Center.

13. Shepard, L., Hammerness, K., Darling-Hammond, L., Rust, F., BaratzSnowden, J., Gordon, E.,etal.(2005).In L. Darling-Hammond \& J.

14. Shute, V. J. (2008). Focus on formative feedback. Review of Educational Research, 78, 153-189.

15. Wiliam, D. (2006). Formative assessment: Getting the focus right. Educational Assessment, 11, 283-289. 